\title{
Increasing Teleworking Skills of Student Translators: Turkish Case
}

\author{
Halil İbrahim BALKUL \\ Department of Translation Studies, Insitute of Social Sciences, Sakarya University \\ Esentepe Campus, Sakarya, Turkey
}

Received: 17-02-2015

Accepted: 28-03- 2015

Published: 01-04- 2015

doi:10.7575/aiac.ijclts.v.3n.2p.48

URL: http://dx.doi.org/10.7575/aiac.ijclts.v.3n.2p.48

\begin{abstract}
This study reflects pedagogical implications derived from "Translation in the $2^{\text {nd }}$ foreign language" course offered at Translation Studies Department at Sakarya University, Turkey in 2014- 2015 academic year / fall term. The insights derived from the classroom sessions were obtained from the instructor's observations based on reflective journals, which were updated on a weekly basis. These observations provided a great deal of qualitative data. The course attendees used a Facebook group forum specifically designed for the course discussions and students-teacher communication. They also received their translation projects and then sent them via Facebook messaging system and email till the deadline identified previously by the instructor. The findings reveal that trainee translators' teleworking skills increased as they became more conscious users of computer assisted translation (CAT) tools and social networks. In this way, they are more adaptable to work with distant colleagues, clients and translation vendors in their future career.
\end{abstract}

Keywords: Teleworking, Tele-Translation, Translation Technologies, Translator Training, Use of Social Network Sites

\section{Introduction}

In translator training, it is highly recommended that student translators get used to working styles and strategies just like professional translators do in translation market (see: Rico-Perez: 2002, Pym: 2005, Gouadec: 2007) With the effects of globalization and online trading, today translators get their translation briefs in virtual translation platforms and carry out their professional tasks online. At the same time, they get in touch with translation vendors, other translators, project managers and proof-readers via mass media vehicles. For this reason, it is inevitable for translation departments to train their students according to the characteristics of the translation market into which their trainee translators will enter in a short period of time. Parallel to the above-mentioned statement, Kiraly notes that learning to be a professional translator means learning to act like one (Kiraly: 2000).

Developing student translators' professional skills can be enhanced with different procedures in translator training programs. Kelly (2005) states that simulations of role-play activities and apprenticeship facilities can be used in translation departments in order to adapt trainee translators into translation industry. On the other hand, some authors namely Vienne (1994), Kiraly (2000) and Gouadec (2003) advocate that real translation briefs need to be assigned to the students by the instructor, not the simulation activities, so as to prepare them for real world translation missions. Here, co-operation with translation industry is strongly underlined.

Olvera-Lobo et al. (2005) put forward an innovative approach to translator training, which they call "Professional Approach to Translator Training (PATT)". They claim that their teaching methodology discards the artificiality which sometimes characterizes translation activities in translator training. In PATT, students are distributed into groups and each group is comprised of the students who take the roles of translator, reviewer, terminologist and project manager. Here, the instructor is in the role of the client and translation briefs are carried out in this frame work; moreover, all communications both among the students and with the instructor are in virtual environment. In this way, the students are encouraged to use mass-media vehicles just like in professional translation environment. Besides, Olvera-Lobo et al. (2005) stated that the students are expected to carry out the following tasks, which are documentation, terminology search, revision, editing and desktop publishing in PATT.

After a brief introduction to the topic, the structure of the current study is formed as follows: The second part of this research focuses on teleworking and tele-translation concepts together with their implications for both translation industry and academic translator training. In the third part of the study, the use of social networks in translator training is tackled with the references from previous researches. Part four is about the methodology of this paper and gives information about data collection method of the research. The following part is related to the context of the study. This part gives information about the institute in which this case study was carried out, the student profile and CAT tools used in the research. In the $6^{\text {th }}$ part of the current study, class work flow is introduced with the procedures administered during lessons. The next part entitled "Results and Discussion" deals with the pedagogical implications derived from the course, especially about the problems of the student translators related to tele-translation and CAT tools usage. Finally, the last part of this study concludes the research with insights for the future researches in the field. 


\section{Teleworking and Tele-translation}

The concept of teleworking has been defined by many researchers in different studies (See: Fritz, Higa \& Narasimhan: 1995, Handy and Mokhtarian: 1996 and Tremblay, Paquet \& Najem: 2006). In this study, we define teleworking as in its simple form, which is a kind of working style performed at home or somewhere else without settling in an office and mostly using mass media sources.

There is no doubt that teleworking is extremely significant for today's translators, especially freelancers. To consider translation market's current position, it is easy to express that translation projects cross beyond national borders and they are accomplished by several translators in a group work by using information technologies, internet forums and the other related communication types. Therefore, it is crucial for trainee translators to acquire teleworking skills in their early years of translation education. In translator training, students must be encouraged to use technology as much as possible and carry out translation projects at a distant base. Emphasizing the importance of teleworking in translator training, Olvera-Lobo et al. (2009) stated that PATT enables students to develop their teleworking skills and not just depend on traditional working procedures.

In a more recent study, Olvera-Lobo and Gutiérrez-Artacho (2014) created a social network called "ning" for the course entitled "Translation 6: Legal, Economic, and Commercial (English into Spanish)" to increase their student translators" teamwork, teleworking and collaboration skills. They made use of "Google Analytics" to monitor how often and for what purposes their students visited the social network site. Their case study showed that the students appreciated the social network site and visited itfor several purposes such as forum discussion, documentation and group work. Also, the students visited "ning" website once or twice a day, which is a good rate according to "Google Analytics".

O'Hagan (1996) put forward the term tele-translation and defined it as a language service for translation provided via telecommunication vehicles. Thanks to the technological developments over years, O'Hagan and Ashwort (2002) defined tele-translation as translation activities operated via the internet and translation of internet-related content. As it is clearly understood from the above-mentioned definitions of tele-translation, it must be kept in mind that technology has changed the way translators do their jobs, communication style of translation industry and translation concept as well. O'Hagan (2006) stated that professional translators would be much more bounded to translation technologies in future so that they could carry out their translation projects via tele-translation and tele-translation is the new paradigm of translation profession. Also, she strongly asserts that translator training institutes must have a role to prepare future translators for prospective translation industry which will be heavily controlled by technological developments in translation profession. Parallel to the ideas reflected above; tele-translation, working in teams and distance learning are stated at the beginning of the innovations expected in translator training in Pym et al. (2003:10).

\section{Use of Social Networks in Translator Training}

There is no doubt that students today are more into using technology compared to the past. Social networks are one of the most-widely used web sites used by young people as well. From pedagogical point of view, it has been found that using social networks for academic purposes is very useful (See: Moran, Seaman \& Tinti-Kane: 2011, Aydin: 2012, Dabbagh and Kitsantas: 2012). Social network sites such as Facebook, Twitter and Linkedin can be used among professional translators for various purposes. Here, the focus will be on professional use of these sites for translators. Sierra and Polo (2011) sort business-like contexts in which translators can use social networks as follows:

a) Viewing content and/or finding information.

b) Getting professional benefits and jobs.

c) Promoting and monitoring their profession-related position, and creating and developing an online presence.

d) Connecting with existing networks, making and developing contacts.

e) Creating, sharing and publishing their personal contents.

f) Keeping up to date with profession, research, tools and techniques.

g) Collaborating with other translators by solving doubts, giving information, etc.

h) Building and maintaining relationships.

In translator training, student translators can be encouraged to use social networks for the above-mentioned situations just like professional translators. Besides, student translators can share course materials with their classmates, get into contact with the instructors and post to the course forums on social networks. What's more, they can contact professional translators and translation service vendors through different translation profession-related forums on social networks. Desjardins (2011) asserts that these forum posts provide insights to the instructors with regards to students' learning curves, their aptitudes, and the areas that need improvement pedagogically. At the same time, more introvert students can better explain their thoughts related to the course and translation world both to their peers and the instructor via social networks.

Similar to PATT, Vargas-Sierra and Ramirez-Polo (2011) developed a new model called "Training Web Interaction and Translation Technologies (TWITT)" with more emphasis on using social network sites for training technologyequipped translators. The figure below demonstrates the mentality and work flow of TWITT model. 


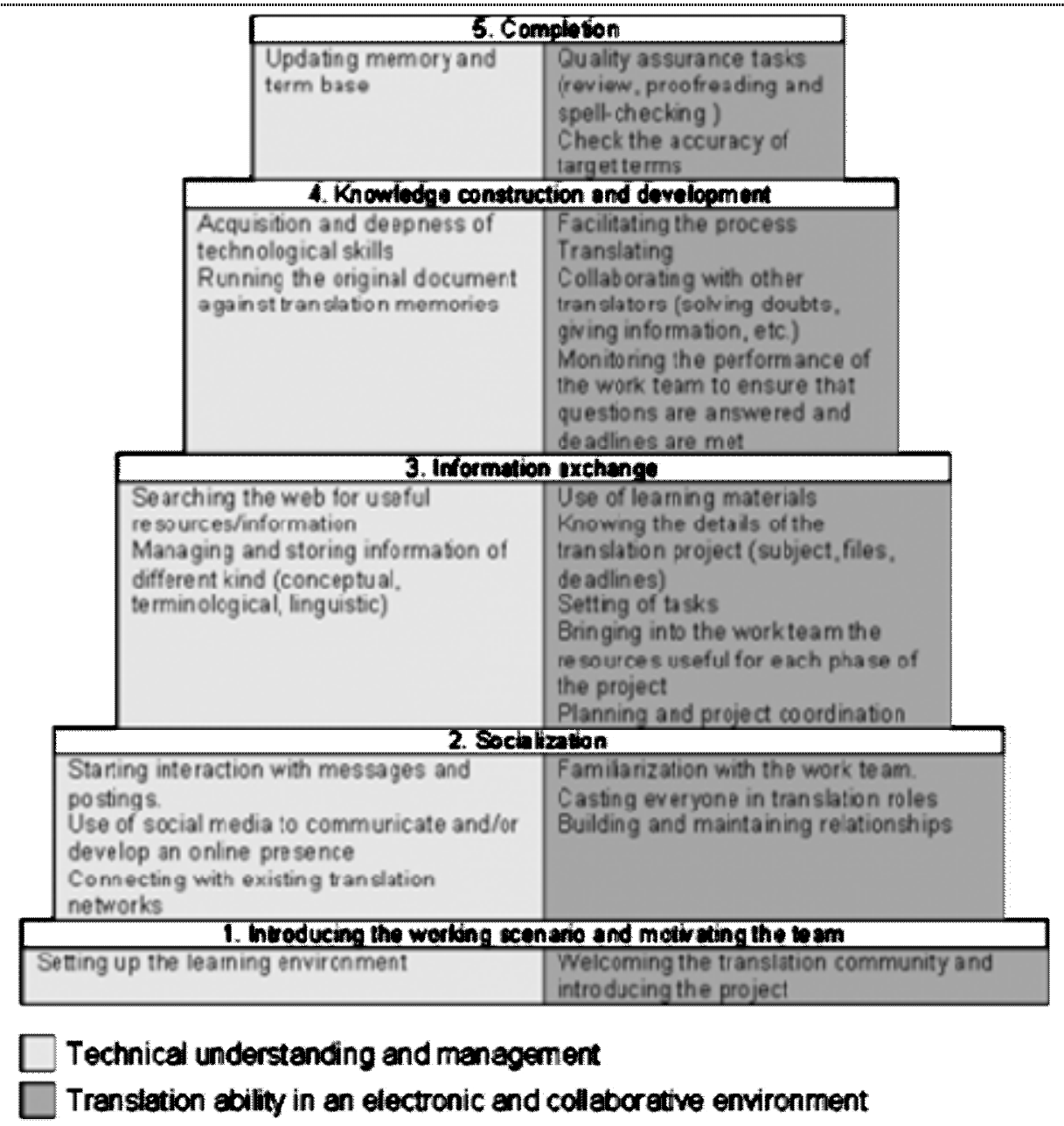

Figure 1. TWITT model (Vargas-Sierra \& Ramirez- Polo: 2011)

The figure consists of five steps, and there are two skills in each step. While the skills on the left are related to technical understanding and management, the skills on the right concern translation ability in an electronic and collaborative environment. The focus on this new model is on the community, the socialization and the information exchange among translation students with the lecturers and other experts.

\section{Methodology}

There is no doubt that reflective writing can foster reflective thinking and reflective thinking seems significant to identify, analyze and solve the complex problems during teaching activities. Spalding, Wilson \& Mewborn (2002) put forward the advantages of keeping reflective journals in training environments as follows: a) journals serve as windows into our students' thinking and learning, b) journals provide a means of establishing and maintaining relationship with students and c) journals serve as dialogical teaching tools. Therefore, the instructor kept reflective journal to observe the progress in trainee translators' teleworking skills, obstacles encountered during translation projects based on teleworking and pedagogical implications for more effective translator training scenarios. The instructor checked his journal at a weekly basis after the courses and pinpointed important issues related to his research aim. The data obtained from the current study is mainly based on a qualitative perspective.

\section{Study Context}

The course entitled as "Translation in the $2^{\text {nd }}$ foreign language" was offered for the $4^{\text {th }}$ year Translation Studies students at Sakarya University, Turkey in 2014-2015 fall term. The students are enrolled in Translation Studies department (German language) at B.A. level. Although English is accepted as their $2^{\text {nd }}$ foreign language according to formal regulations, the majority of the students acquired English earlier than German. Most of them graduated from English foreign language departments at high school but they chose German Translation Studies department at university for several reasons such as job opportunities in future or lack of English proficiency grade at university entrance exam. To this end, it can be put forward that the students are at least as competent in English as in German.

Total number of participant students was 20 during the course and all the students come from the same mother language background, which is Turkish. The study group met four hours a week during the term which lasted totally 13 weeks. Besides, the instructor and the students selected an area of expertise about which they will carry out translation projects. At this stage, it was important to decide on which topic classroom translations will focus. The instructor interiorized 
social constructivist approach and let the students be a part of syllabus design. The students were also allowed to state their expectations from the course. The students and the instructor reached a compromise on "foreign trade" as the area of expertise during the course. In this way, the students were motivated to be more into the classes. Additionally, the translation projects during the classes were aimed to be carried out on open-source translation software, "Wordfast Anywhere". In this way, it was aimed to motivate the students' use of computer assisted translation tools as well. "Wordfast Anywhere", being open-source translation software, lets the students reach the tool anywhere they have internet connection. Unlike commercial translation workbenches, the above-mentioned software requires neither membership fee nor installation procedures.

\section{Class Work Flow}

The course entitled "Translation in the $2^{\text {nd }}$ foreign language" lasted 13 weeks during 2014-2015 fall term. The classroom attendees met 4 hours a week. Except from exam days and official holidays, the class met 10 weeks during the term. At the first week of the course, the students were assured that they need to develop their professional teleworking skills and technology use skills so as to be successful in competitive professional translation market. Additionally, they were encouraged to read the suggested articles and book chapters related to the topic. In the second week, the instructor assigned a responsible and techno-geek student to open a Facebook group for course discussions and students-teacher communication. Also, the teacher demonstrated the fundamental usage areas of "Wordfast Anywhere" software at that week and asked the students to enroll in the above-mentioned platform. Thanks to the course entitled "Computer-assisted translation" which was offered to the students in their $3^{\text {rd }}$ year, the students were used to translating in translators' workbench.

In the following weeks, the instructor assigned translation briefs to the students through Facebook group channel each week and wanted the students to get prepared for translation-oriented text analysis discussions which would be carried out in the face to face class sessions. After face to face sessions, the students were asked to translate the analyzed texts about foreign trade of Turkey at home by using "Wordfast Anywhere". During the courses, main usage skills of desktop publishing tools such as Adobe programs were taught as well. The students were grouped into 5 and each group member was responsible for the ultimate translation product. The students got into contact with group members via Facebook group, email and other telecommunication vehicles. Some of the students stated that they used "skype" for conference calls among their friends and they could easily discuss translation problems and many other related topics.

When translation briefs were completed, the students were asked to write a translation commentary. Here, the students were supposed to indicate the purpose of their translation briefs, target readership of the translated text and the problems encountered during the translation. In this way, it was aimed to be aware of the students' problems and help them as early as possible. During the course, the students were assigned 5 translation briefs and a final project, all of which were delivered to the students and accepted from them via Facebook messaging system or e-mail. For the assessment of students' translations, a process-oriented approach was used. Rogers and Korkas (2005) note that technology-oriented translation classes and the projects for these classes cannot be assessed with traditional assessment approach which focuses on translation product. Instead, the process in which the students use technology and carry out translation projects needs to be evaluated by a process-oriented approach. While grading their success related to the course; classroom discussions, Facebook group forum discussions, translation commentaries and co-operation skills with other group members at distant pace were taken into consideration.

\section{Results and Discussion}

The themes obtained from reflective journals of the instructor are displayed here for the sake of pedagogical implications of the course. At the beginning of the course, the students were not used to carrying out teamwork at a distant pace. Therefore, it wasn't easy for the instructor to encourage them for teleworking. Actually, the learners showed resistance for teamwork due to the fact that some of their friends were not responsible enough to complete the projects before the deadline. When the learners were aware of the instructor's persistence for teamwork, they started to set up a closer friendship among their group members. At that time, the instructor posted warnings related to the importance of teamwork and active participation for translation projects in Facebook group forum. Also, the students were reluctant to be assessed for their translation projects as a group; however, they were convinced of the necessity for such kind of an assessment type as they were shown the realities of professional translation projects. The instructor provided authentic data displaying that all group members were responsible for the whole translation product in professional setting and he assured that if they failed in any step of the project, all fellow translators would be affected badly.

The second problem encountered during teleworking procedures among student translators is related to their poor IT skills. In spite of the fact that all the learners were perpetual users of internet, they lacked of using main wordprocessors, converting the documents (from pdf to word or vice versa) and handling spread-sheet programs. In the early years of translator training at Sakarya University, the students take "General IT skills" course, however it seems that the learners failed to improve their skills further after a few years. To overcome IT skills problems of the learners, the instructor devoted a few hours of the course to repeat and display the use of main office programs and desktop publishing tools. What's more, the students with low IT skills were grouped with the ones with high IT skills. In this way, both teamwork and peer-support were aimed, which gave positive results.

Another problem indicated by the students related to teleworking in our case study is the lack of internet connection facilities. Some of the students stay in university dormitories while the others live with their families or friends. 
Actually, the indicated problem does not reflect the real situation. Firstly, university dormitories provide the students with 7 / 24 internet connection; moreover, university library is open all time including nights and official holidays with full-time internet connection. Additionally, there is an internet room in the faculty allowing students to use internetconnected computers. For this reason, the students were assured to be informed about the above-mentioned internet use facilities and they were encouraged to make use of these facilities.

At the beginning of the course, the students had a negative attitude towards computer-assisted translation in spite of the fact that they took a course related to computer-assisted translation in their $3^{\text {rd }}$ year. However, the more they were acknowledged with the state-of-the-art technology in translation and the reflections of them in translation industry, the more positive attitudes they displayed towards teleworking, teamwork and computer-assisted translation. Reading the opinions of famous translation scholars and being aware of the current state of translation industry, the learners started to be more willing to carry out their translation projects online with the help of translation technologies.

Another problem during the course flow was the technical maintenance in "Wordfast Anywhere". At the time of maintenance, the students had difficulty in reaching the software online and they reported this problem in Facebook discussion forum. However, this kind of problem is possible to occur in professional settings as well. Therefore, the learners were encouraged to carry out their translations by using office programs till the end of the maintenance. Although the mentioned problem seemed to be a negative situation from a professional point of view, it was actually useful pedagogically. All in all, the ultimate goal of a training environment is to prepare the learners for real-life situations. Both the learners and the instructor had an insight related to the above-mentioned problem. The students developed their problem-solving strategies and they could better understand the words of Mossop (2003: 20) related to the issue:

"If you can't translate with pencil and paper, then you can't translate with the latest information technology".

The last trouble met during the course was related to terminology. As it was stated above, the domain-specific translation area was "foreign trade of Turkey" for the course. Even though the most of the learners were interested in the topic, they nearly had no terminological background related to foreign trade. For this reason, they complained about terminological problems in their translation commentaries that they wrote after each translation brief. After a few weeks, the instructor realized the problem and he suggested the learners reading parallel texts in foreign trade both in mother language and foreign language. At the same time, they were able to set up their domain-specific terminology database both in "Wordfast Anywhere" and in their personal terminology banks. Furthermore, the instructor asked the learners to write down every new terminology they learned after each translation project and discuss the use of these domain-specific words in different contexts with their group members in "Facebook group forum". In this way, it was aimed both to encourage them to appreciate their peers' ideas and increase their teleworking skills and use of translation technologies.

\section{Conclusion}

The present study mainly focused on how to improve teleworking skills of student translators using a specific social network site and CAT tools with a constant emphasis on teamwork. By using reflective journals as a data collection method, the researcher obtained valuable insights related to his translator training context, however, the findings of this research can be utilized by other translator trainers from different parts of the world. The problems during teaching process in this study are generally not country-specific but cross-globe issues. Despite being unwilling and suspicious about teleworking and using CAT tools in the beginning, the student translators started to show more positive attitudes at the end of the course. The most common problems encountered during training were unwillingness for teamwork, poor IT skills, internet connection facilities, technical problems related to the software and terminology of foreign trade which was the area of expertise for translation projects. The instructor and the students handled with these problems thanks to careful observations during the course and pedagogical implications which were presented in previous academic researches.

What is strongly keynoted in constructive teaching methodology is that an instructor must be a facilitator in a teaching and learning environment. In this way, both students can be responsible for their own learning process and team-work among students can be enhanced. In this regard, the instructor in this case study helped his trainees get some valuable transferrable skills to which they can apply in their professional translator career. Last, but not the least, it needs to be emphasized that students enrolled in translator training programs are required to be motivated not to fall behind technology and current developments in translation industry and interiorize a life-long learning mentality by which they can keep on learning every time, everywhere.

\section{References}

Aydin, S. (2012). A review of research on Facebook as an educational environment. Educational Technology research and development, 60(6), 1093-1106.

Dabbagh, N., \& Kitsantas, A. (2012). Personal Learning Environments, social media, and self-regulated learning: A natural formula for connecting formal and informal learning. The Internet and higher education, 15(1), 3-8.

Desjardins, R. (2011). Facebook me!: Initial insights in favour of using social networking as a tool for translator training. Linguistica Antverpiensia, New Series-Themes in Translation Studies, (10) 175-194.

Fritz, M., Higa, K. \& Narasimhan, S. (1995). Toward a Telework Taxonomy and Test for Suitability. Group Decision and Negotiation, (4:4), 311-334. 
Gouadec, D. (2003). Notes on Translator Training. In: A. Pym, C. Fallada, J.R. Biau and J. Orenstein (Eds.).

Innovation and E-learning in Translator Training. Tarragona: Intercultural Studies Group, 9-11.

Gouadec, D. (2007). Translation as a Profession (Vol. 73). Amsterdam: John Benjamins Publishing.

Handy, S. \& Mokhtarian, P. (1996). The future of telecommuting. Futures, 28(3), 227-240.

Kelly, D. (2005). A handbookfor Translator Trainers, Manchester: St. Jerome Pub.

Kiraly, D. (2000). A social constructivist approach to translator education: Empowerment from theory to practice. Manchester: St. Jerome Pub.

Moran, M., Seaman, J. \& Tinti-Kane, H. (2011). Teaching, Learning, and Sharing: How Today's Higher Education Faculty Use Social Media. Babson Survey Research Group.

Mossop, B. (2003). What should be taught at translation school? In: A. Pym, C. Fallada, J.R. Biau and J. Orenstein (Eds). Innovation \& E-Learning in Translator Training. Tarragona: Intercultural Studies Group, 20-23.

O’Hagan, M. (1996). The Coming Industry of Teletranslation. Clevedon: Multilingual Matters.

O'Hagan, M. \& Ashworth, D. (2002). Translation-mediated communication in a digital world: Facing the challenges of globalization and localization. Clevedon: Multilingual Matters.

O’Hagan, M. (2006) Teletranslation revisited: Futurama for screen translators? In MuTra, Audiovisual Translation Scenarios, 1-12.

Olvera-Lobo, M. D., Castro-Prieto, M. R., Quero-Gervilla, E., Muñoz-Martín, R., Muñoz-Raya, E., Murillo-Melero, M., ... \& Domínguez-López, C. (2005). Translator training and modern market demands. Perspectives: Studies in translatology, 13(2), 132-142.

Olvera-Lobo, M. D., Robinson, B., Senso, J. A., Muñoz-Martín, R., Muñoz-Raya, E., Murillo-Melero, M., ... \& Conde-Ruano, T. (2009). Teleworking and collaborative work environments in translation training. Babel, 55(2), 165180 .

Olvera-Lobo, M. D. \& Gutiérrez-Artacho, J. (2014). Academic use of custom social networks in translation training. Perspectives: Studies in translatology, 22(2), 282-289.

Pym, A., Fallada, C., Biau, J.R. and Orenstein, J. (Eds.) (2003): Innovation and E-Learning in Translator Training: Reports on Online Symposia, Tarragona: Universitat Rovira I Virgili.

Pym, A. (2005). Training Translators: Ten Recurrent Naiveties. Translating Today 2(1), 3- 6.

Rico-Pérez, C. (2002). The profile of the professional translator. Developing competencies for a rapid incorporation into the industry. Simposi sobre l'Ensenyament a distància $i$ semipresencial de la Tradumàtica, 1-8.

Rogers, M. \& Korkas, V. (2005). Technology in the translation curriculum: A process-oriented approach to assessment. In: D. Gouadec (Ed.) Traduction, Terminologie, Rédaction. Actes du colloque international «Traduction et Technologie(s) en pratique professionaelle en formation et en applications de formation à distance» 115-121.

Spalding, E., Wilson, A. \& Mewborn, D. (2002). Demystifying reflection: A study of pedagogical strategies that encourage reflective journal writing". The Teachers College Record, 104(7), 1393-1421.

Tremblay, D.G., Paquet, R. and Najem, E. (2006). Telework: a way to balance work and family or an increase in work-family conflict? Canadian Journal of communication, 31(2), 715-731.

Vargas-Sierra, C. \& Ramírez-Polo, L. (2011). The Translator's Workstations revisited: A new paradigm of translators, technology and translation. Tralogy, Session 4 - Tools for translators/ Les outils du traducteur. Retrieved from: http://lodel.irevues.inist.fr/ tralogy / index.php?id=71 (December 18, 2014).

Vienne, J. (1994). Toward a pedagogy of 'translation in situation. Perspectives: Studies in Translatology, 2(1), 51-59. 